\title{
EDITORIAL
}

\section{SOME TRENDS IN THE DEVELOPMENT OF ADULT EDUCATION - ADULT EDUCATION AT THE CROSSROADS OF SCIENCE, POLITICS AND PRACTICE}

Adult education only emerged as a scientific field of study in the late 1920s, primarily in Europe and the USA, and has, according to Rubenson (2010), since gone through three different phases of development.

The first phase, dating back to the 1920s, developed in reaction to the early professionalisation of adult education. As the number of adult education study programmes rose, universities began to consider the problem of establishing the kind of disciplinary knowledge required to assist in developing this newly emerging field. The first university study programme in adult education was developed and implemented at Columbia University in 1930. By 1964, the year that marks the beginning of the second phase of development, 16 US universities offered master and doctoral programmes in the field of adult education. In Europe, a similar trajectory can be traced in the United Kingdom, where the rising interest in adult education research led to the first university chair in adult education being established at the University of Nottingham in 1926 (ibid., pp. 7-8).

In 1964 the US Commission of Professors of Adult Education defined and conceptualised the foundations of adult education in the publication Adult Education: Outlines of an Emerging Field of University Study; this compendium is also known as the "Black Book" and marks the beginning of the second phase in the development of adult education. In this stage, the process of emergence of the field of study is related to a direct response to the needs found in adult education practice. It is precisely the questions of adult teaching and learning that come to the forefront, which means that the field of adult education is closely linked to educational psychology. Between the publication of the original "Black Book" and its 1991 companion piece entitled Adult Education: Evolution and Achievements in a Developing Field of Study, the number of adult education departments and university study programmes in the USA, Canada and Europe - in Germany, the United Kingdom, Sweden, Finland, the Netherlands, France, Poland, ex-Yugoslavia (including Slovenia), and other European countries (cf. Savićević, 1999, pp. 209-228; Krajnc, 2011) - saw a great rise, with the organisation of many annual conferences on 
adult education, the establishment of scholarly journals (e.g., Adult Education Quarterly) and associations (e.g., ESREA - the European Society for Research on the Education of Adults), etc. (Rubenson, 2010, p. 8). At the same time, adult education, defined as andragogy, is established as a relatively independent scientific discipline in the USA and some European countries, especially in Central and Eastern Europe - including ex-Yugoslavia. It builds on conceptual differentiation between adult learners and children, and focuses on researching adult learning and education (Fejes and Nicoll, 2013; Krajnc, 1989; Savićević, 2008).

In other parts of the world, particularly in developing countries (some countries in Africa and Latin America), the process of establishing specialised departments and university study programmes in adult education took longer to commence and is currently characterised by traits typical of the first phase of development. In Brazil, there is a noticeable increase in the number of departments and study programmes dedicated to adult education, and China saw its first master programme in adult education introduced at the East China Normal University in 1993 (Rubenson, 2010, p. 8).

Reflecting on the evolution and the accomplishments of the developing field of adult education up until the 1990s, Peters and Jarvis (1991) presented a very optimistic perspective on the development of this field based on the considerable increase of disciplinary knowledge base, the diminishing dependence on related disciplines, the improvements in research methodology, the exponential growth in terms of study programmes and a greater internationalisation of the adult education field. In their discussion, they came to the conclusion that the adult education field would experience continuous growth in the following 25 years, leading to even firmer positioning of the discipline in the academic sphere.

Rubenson (2010) finds, however, that at the beginning of the $21^{\text {st }}$ century there are several signs that the development of adult education is not going in the direction foreseen by Peters and Jarvis, and that, since the mid-1990s, adult education is witnessing a transition to a new, third phase of development. It is typical of this stage that the growth of specialised departments and study programmes in adult education (as experienced in the second phase) has not continued, with a new trend emerging instead: adult education programmes and departments have begun to merge with other fields to create larger departments, and there have also been some cases of universities abolishing specialised adult education departments. The author sees a multiplicity of reasons for this process. First, the mergers are a consequence of the broader restructuring of university departments into larger structures, which as a rule makes it difficult to establish the field of adult education in the manner characteristic of the second phase. Second, the implementation of the principle of lifelong learning, heavily promoted by various international organisations Europe- and worldwide, represents an obstacle to establishing the field of adult education as an independent discipline. Third, given that workplace education is the fastest growing part of adult education practice, adult education researchers are compelled to undertake work-related learning and education research. Consequently, what is noticeable is the ever greater fragmentation of the field into several subfields; for instance, the field of 
workplace education is being established as an alternative field to adult education with its own conferences and specialised scholarly journals. Fourth, the field of adult education is facing a general trend typical of all fields within education science, namely moving from the establishment of discrete fields and disciplines to the creation of knowledge about some common topics (e.g., gender, migrants, etc.) approached from an interdisciplinary research perspective. This makes it necessary for adult education researchers to develop alliances with various other disciplines (ibid., pp. 8-9).

From a historical perspective, the development of adult education in its first and second phases grew out of concern for developing the practice of adult education. There are, nevertheless, different opinions among scholars and researchers in the field as to whether adult education is primarily a field of practice (Rubenson, 2000), i.e., a subject area whose goal is to develop tools that will help practitioners respond to work challenges, or instead a scientific discipline that should strive for greater theoretical sophistication with the aim of improving its academic reputation (Rubenson, 2010).

In the 1970 s and 1980s, the tense relationship between theory and practice led to a discussion about the link between theory, i.e., disciplinary knowledge base, and the status of adult education. If adult education is to be an independent discipline and research field, this means it must define its research focus and develop its own scientific theories. As shown by the first and second developmental phases in adult education, the empirical criterion, with its demand for the establishment of university chairs in the field (of adult education) as a necessary component to the establishment and acknowledgement of adult education as a subject of research at university level, was already met in the first phase of development. The establishment of adult education chairs in American and European universities can thus be understood as an important step towards acknowledging and solidifying adult education as a separate scientific discipline and field of study (Fejes and Nicoll, 2013).

If the empirical criterion for acknowledging adult education as a separate scientific discipline was fulfilled, positions on satisfying the epistemological criterion, which provoked a broad epistemological discussion on the nature of adult education among active adult education scholars and researchers, can be divided into at least three main schools of thought. Some authors within the first school, which was characteristic primarily of the USA and ex-Yugoslavia (including Slovenia), believed that adult education was an independent scientific discipline which was to stop borrowing theories and concepts from other disciplines, developing instead its own, as borrowing from other disciplines could endanger the further development of adult education disciplinary knowledge base. The second and more popular school promoted the idea of adult education as a subject of study producing interdisciplinary knowledge applicable in practice. The third school rejected the concept of adult education as an independent subject discipline or theoretical subject area, seeing adult education as part of education in general, where both education and adult education were understood as social and practical areas that were not based on a disciplinary logic but on practical knowledge distinct from disciplinary knowledge. 
These discussions about the epistemological status of adult education which dominated the 1970s and 1980s saw a decline in the 1990s and almost entirely disappeared at the dawn of the new century. According to Rubenson (2000), the question of borrowing from other disciplines was already passé by the mid- and late 1980s, as most scholars in the field of adult education championed the idea of adult education as a separate theoretical field of knowledge. What is particularly noticeable at the turn of the century is the scholarly efforts to include the theoretical work of researchers in other areas, disciplines and traditions in the field of adult education, as demonstrated in Europe by various ESREA network activities (Fejes and Nicoll, 2013). Nonetheless, this process is not without pitfalls; Rubenson (2000) argues that in the third phase of development, the concern about the lack of a theoretical basis for adult education has led to some researchers being overly preoccupied with the development of abstract theoretical concepts divorced from practice, which can, in consequence, cause a decline in the practice of adult education if the latter is not supported by theoretical research, as pointed out in the Slovenian context by Krajnc (2011, p. 15).

Thus, there is a consensus in the international sphere today regarding the epistemological status of adult education; the field of adult education is essentially interdisciplinary and pluralistic, borrowing theories and methodologies from various disciplines and fields of knowledge (Fejes and Nylander, 2015).

In a similar vein, in the third phase in the development of adult education the field also turns out to be very diverse across countries in terms of target groups, teaching content, providers, institutionalisation, funding and legislation. This diversity must surely be a challenge to a greater professionalisation of adult education on a practical level, while on the theoretical level there are ongoing discussions about what adult education means or ought to mean today, and what it comprises in various parts of the world (Jütte and Lattke, 2014).

When pondering the status of adult education as a scientific discipline in the currently ongoing third phase of development, Agnieszka Bron and Peter Jarvis (Bron and Jarvis, 2008) - authors coming from two different traditions of education (the latter from the Anglo-Saxon tradition advocating adult education and the former the Continental (Eastern) European tradition advocating andragogy) - conclude that adult education is a new scientific discipline which is called "adult education" by some and "andragogy" by others (e.g., in Slovenia, Poland, parts of Germany, etc.). Most frequently it is understood as a subdiscipline of education science or of pedagogy. Its goal is to examine adult learning and education in both formal and non-formal education (i.e., in organised education), as well as informal learning (i.e., as part of everyday life, at work, in the family, civil society and leisure activities), which constitutes its own special field of study; it examines the opportunities and conditions for adult education and learning, adult formation ("Bildung"), socialisation and development, as, throughout their lives, adults go through the process of learning and develop, change their lives and influence each other. The discipline of adult education has developed its own terminology and concepts, including terms such as 
learning, lifelong learning, self-directed learning, continuing education, etc. The related disciplines that can be of help to adult educators in researching the field primarily include social science, psychology, history, philosophy, economics, and political science. Most commonly, research is executed on four different levels: mega (policies of international organisations), macro (national policies and practices), meso (educational institutions, various - volunteer, cultural, political, etc. - organisations, communities, public spaces), and micro (adult learners) levels.

Recently, research into developmental trends in the field of adult education shows an increasing interest in so-called bibliometric analyses which bring insights into the development of the field based on the analysis of the most reputable, distinguished or cited journals in the field (e.g., Fejes and Nicoll, 2013; Fejes and Nylander, 2015; Rubenson and Elfert, 2015). These studies show that, geographically speaking, Anglo-Saxon countries dominate the field of adult education; the three most dominant and widely recognised journals in the discipline are the Adult Education Quarterly (USA), International Journal of Lifelong Education (United Kingdom), and Studies in Continuing Education (Australia). Authors in these countries also only ever cite authors from these same dominant Anglo-Saxon countries. One more British journal, Studies in the Education of Adults, is included in the selection of dominant publications in the field. Among other influential journals in the field of adult education, but published outside the dominant Anglo-Saxon sphere, the above-mentioned authors include the International Journal of Continuing Education \& Lifelong Learning, based in Hong Kong and focusing on the development of adult education in Asian countries, the European Journal for Research on the Education and Learning of Adults, which is published by ESREA and serves as a forum for adult education researchers across Europe, and finally the International Review of Education, published by the UNESCO Institute for Lifelong Learning and dedicated to the development of education and adult education in developing countries.

Based on bibliometric analyses of articles in the dominant scholarly journals in the field of adult education, the authors point out that the field of adult education has experienced significant changes in the third phase of development compared with the first two: (a) in terms of methodology, qualitative research is coming to the fore, while quantitative research is in decline; (b) in terms of theory, there is a dominance of socio-cultural perspectives (e.g., Vygotsky), critical pedagogy (e.g., Freire), and post-structuralist theories (e.g., Foucault); (c) in terms of geography, the field is dominated by authors from the Anglo-Saxon sphere; (d) in terms of gender, the number of female authors is on the rise while the number of male authors is in decline; (e) the field of adult education is increasingly fragmented (borrowing theories and methods from various disciplines); (f) there is a widening gap between academic research in adult education and the policy of adult education shaped more and more by international and political organisations (Fejes and Wildemeersch, 2015). Such organisations strive to establish a tradition of "evidence-based adult education policy" and outcome-based education, such as instantiated by the PIAAC (Programme for the International Assessment of Adult Competencies) 
OECD survey, whose aim is to provide the basis for developing evidence-based policy (Kump and Mikulec, 2017). If international and political organisations thus largely promote adult education policy-making related to the skills-oriented discourse, this type of discourse is only marginally present in academic research in the field or adult education, which only serves to further broaden the divide between academic research in the discipline and adult education policy (Rubenson and Elfert, 2015).

The editorial team of this journal would like to encourage bibliometric analyses of articles published in scholarly journals in the field of adult education in Slovenia (such as Andragoška spoznanja/Studies in Adult Education and Learning), in other ex-Yugoslav countries (such as Andragoške studije/Andragogical Studies), and in countries of Continental and Eastern Europe (such as Dyskursy Młodych Andragogów/Adult Education Discourses), viz., in environments with an established tradition of andragogy. Such an undertaking would show whether in this part of Europe the trends of development in the field of adult education are similar to or different from the trends in the dominant (Anglo-Saxon) scholarly journals which exhibit a decisive influence on the field of adult education.

This open issue of Studies in Adult Education and Learning comprises three scientific and three professional articles, a report and a book review. The first paper by Eva Klemenčič, "Opinions of Adult Learning Institution Managers on the Impact of Erasmus+ on Adult Education: The Case of Slovenia" examines the impact of the Erasmus+ programme in Slovenia at both institutional and systemic levels. The author sees the Erasmus+ programme as an example of the Europeanisation of the (adult) education system exhibiting impact on institutions in the field of education, public policies, and common values. The empirical study involved shows that managers of adult learning institutions in Slovenia mainly have a positive opinion about the impact of the Erasmus+ programme on adult education in Slovenia (in terms of professional development, organisational climate, quality, and "European added value"), but that there is also some indecision about how well the national guidelines for adult education match the needs of adult education institutions.

Anita Jug Došler and Margerita Zagmajster's paper “Centres for Self-directed Learning (CSDL): Current Challenges, Recommendations and Future Development" explores the development of organised self-directed learning worldwide and in Slovenia, where the concept was first implemented in 1993. According to the findings, the number of participants in the network of centres for self-directed learning in Slovenia increases year after year. Acknowledging a need for the continued improvement and expansion of centres for self-directed learning, the authors suggest an array of proposals for further development of organised self-directed learning.

The third article, "Aspects of Foreign Language Learning at the Third Age University" by Tanja Miklič, focuses on foreign language learning in the third age. Based on a theoretical and empirical investigation, the author finds that the learning materials, the structure of the learning process and the learning forms and methods are not sufficiently adapted 
to either the health limitations of older adults or to the current findings in adult education and gerontology. A number of possible measures are proposed to address these shortcomings.

In her paper "Adult Educational Guidance Between Theory, Educational Policy and Practice", Tanja Vilič Klenovšek examines the various definitions of guidance as developed in theory, education policy, and adult education practice. The author emphasises the key goals and tasks for guidance work in adult education, as well as the strategic aims for the development of this area in the system of adult education, now that there is a legal basis for the implementation of counselling thanks to the new Slovene Law on Adult Education (2018)

Polona Klemše's article "Active Employment Policy for Youth: Youth Guarantee” analyses the 2014-2015 active employment policy for youth, whose aim was to promote youth employment and youth activity in the labour market. The author finds that despite this ambition, the measures that were part of the scheme did not make a significant contribution to youth employment levels in Slovenia.

In their paper "The Problem of Word Acquisition Under the Influence of Globalisation", Mihaela Drobnič and Maruša Grilj tackle the issue of adopting new global expressions into Slovene. Brought about by the rapid development of technology, this phenomenon leaves many adults unable to fully comprehend the new vocabulary that is being established on the internet and social media.

Finally, the present issue also includes two more interesting contributions: Ida Srebotnik's report "Building Bridges in Adult Education", an account of professional cooperation of adult education experts in ex-Yugoslav countries; and a book review by Danijela Makovec reporting on the proceedings volume Cultures of Program Planning in Adult Education.

\section{Borut Mikulec}

\section{REFERENCES}

Bron, A. and Jarvis, P. (2008). Identities of Adult Educators: Changes in Professionality. In E. Nuisll and S. Lattke (eds.), Qualifying adult learning professionals in Europe (pp. 33-44). Bielefeld: Bertelsmann W.

Fejes, A. and Nicoll, K. (2013). Editorial: Approaches to research in the education and learning of adults. European Journal for Research on the Education and Learning of Adults, 4(1), 7-16.

Fejes, A. and Nylander, E. (2015). How pluralistic is the research field on adult education? Dominating bibliometrical trends, 2005-2012. European Journal for Research on the Education and Learning of Adults, 6(2), 103-123.

Fejes, A. and Wildemeersch, D. (2015). Editorial: cartographies of research on adult education and learning. European Journal for Research on the Education and Learning of Adults, 6(2), 97-101.

Jütte, W. and Lattke, S. (2014). International and comparative perspectives in the field of professionalisation. In S. Lattke and W. Jütte (eds.), Professionalisation of Adult Educators: International and Comparative Perspectives (pp. 7-21). Frankfurt am Main: Peter Lang. 
Krajnc, A. (1989). Andragogy. In C. J. Titmus (ed.), Lifelong Education for Adults: An International Handbook (pp. 19-21). Oxford: Pergamon Press.

Krajnc, A. (2011). Študij andragogike in izobraževanje andragogov. Andragoška spoznanja, 17(2), 12-27.

Kump, S. and Mikulec, B. (2017). Raziskava PIAAC kot orodje za oblikovanje na podatkih temelječe politike izobraževanja odraslih: primer analize neekonomskih dejavnikov pri oblikovanju politike aktivnega staranja. Sodobna pedagogika, 68(4), 14-33.

Peters, J. M. and Jarvis, P. (eds.) (1991). Adult Education: Evolution and Achievements in a Developing Field of Study. San Francisco: Jossey-Bass.

Rubenson, K. (2000). Revisiting the Map of the Territory. In T. J. Sork, V.-L. Chapman and R. St. Clair (eds.), Proceedings of the Annual Adult Education Research Conference (pp. 397-401). Vancouver: University of British Columbia.

Rubenson, K. (2010). Adult Education Overview. In P. Peterson, E. Baker and B. McGaw (eds.), International Encyclopedia of Education: Third edition (vol. 1) (pp. 1-10). Oxford: Elsevier.

Rubenson, K. and Elfert, M. (2015). Adult education research: exploring an increasingly fragmented map. European Journal for Research on the Education and Learning of Adults, 6(2), 125-138.

Savićević, D. M. (1999). Adult Education: From Practice to Theory Building. Frankfurt am Main: Peter Lang.

Savićević, D. (2008). Convergence or divergence of ideas on andragogy in different countries. International Journal of Lifelong Education, 27(4), 361-378. 